Caligrama, Belo Horizonte, v. 23, n. 2, p. 165-182, 2018

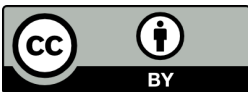

\title{
Narrações-munições: sinais da memória violenta nos contos testemunhais de Reinaldo Arenas
}

\section{Weapon-Narratives: Signs of Violent Memory in the Testimonies' Tales of Reinaldo Arenas}

\author{
Antonio Martínez Nodal \\ Instituto Cervantes, Salvador, Bahia / Brasil \\ antonio.nodal@gmail.com \\ Carla Dameane Pereira de Souza \\ Universidade Federal da Bahia, Salvador, Bahia / Brasil \\ carladameane@gmail.com
}

Resumo: Neste artigo analisamos a presença autoral de Reinaldo Arenas em suas narrativas breves exponencialmente autobiográficas, procurando, nessas vivências, singulares batalhas e desacordos com o Estado cubano revolucionário e o espaço afetivo coercitivo de sua escrita. $\mathrm{O}$ confronto das interpretações e as leituras da realidade do escritor dissidente com a história oficial podem-nos ajudar a identificar descrições ocultas na narrativa dos textos breves memoriais de Reinaldo Arenas e, consequentemente, a revelar alguns importantes conteúdos histórico-políticos e autoficcionais inseridos nos citados relatos. Desta maneira, os contos funcionam como narrações-munições, isto é, gestos literários que se revelam como ações simbólicas de resistência e de denúncia do sistema totalitário fidelista e de seu universo filial. Explicita-se, ademais, o componente testemunhal de suas fortes narrativas observado nas características de alguns relatos pertencentes à obra Termina el desfile (1981), que contém as variadas passagens histórico-críticas assinaladas na vida de Arenas, potencializadas pela violência familiar e a pulsão sexual latente do escritor cubano.

Palavras-chave: Reinaldo Arenas; narrações-munições; testemunho.

Abstract: This article aims to analyze Reinaldo Arenas' presence as an author in his autobiographical short narratives; seeking in these experiences singular battles and 
disagreements with the Cuban revolutionary state and the coercive-affective space of his writing. The readings of the reality of the dissident writer coupled with the official history can help us to identify hidden descriptions in the narrative of the short memorable texts of Reinaldo Arenas through the confrontation of the interpretations. Thus, consequently reveals some important historical, political and auto-fictional contents inserted in the cited reports that function as weapon-narratives. That is, literary gestures that are revealed as symbolic actions of resistance and denunciations of the totalitarian system of Fidel and its filial universe. The testimony component of his powerful narratives is also explained, and finally we analyze some of the short stories belonging to Termina el desfile (1981), which contains the various historical-critical passages in the life of Arenas, reinforced by family violence and the latent sexuality drive of the Cuban writer.

Keywords: Reinaldo Arenas; weapon-narratives; testimony.

\section{Introdução}

As narrativas curtas em primeira pessoa de Reinaldo Arenas (1943-1990) são a base constitucional de seu livro de relatos Termina el desfile (1981), documentos ficcionais cuja voz autobiográfica recorrente nos permite examinar sua literatura de forma mais tangível, tanto física quanto ideologicamente, ao se revelar a palavra mais íntima desse escritor cubano. Sendo assim, buscamos um aprofundamento de alguns vestígios memoriais definidos em sua imprevisível percepção do mundo refletida numa literatura arrebatada e híbrida por compreender a literatura e sua relação com a história e com a política. As variadas possibilidades de cotejamento do literário de sua escrita, o simbolismo inerente no discurso e a rotunda expressividade de uma narrativa liberada, foram as características distintivas de seus textos que nos permitem justificar a aproximação a suas narrações breves plurissignificativas.

A complexidade da narrativa curta de Reinaldo Arenas foi intencionadamente dramatizada, superdimensionada pela voz crítica do autor, influenciado pelos acontecimentos dolorosos padecidos em seu país, Cuba. A perseguição policial sofrida culminaria com seu ingresso na prisão de Morro entre 1974 e 1976, reproduzidas nas múltiplas constelações dramático-literárias inseridas nos relatos do atual estudo. Optamos pela escolha dos contos deste autor cubano como núcleo literário do artigo com a pretensão de sinalizar algumas marcas narrativas de 
intensidade ${ }^{1}$ máxima, pois, como a escritora espanhola Ana María Matute (1998) declarava, mediante o conto precisa-se dizer o máximo através do mínimo, para, dessa maneira, acometer um golpe maior na transposição de uma história, de um sucesso que precisa ser desvendado.

O caráter imprevisível da literatura de Reinaldo Arenas estabelece um encontro de órbitas que se enfrentam e que podem ser observadas como narrações-munições, pelo caráter extremo e agressivo do discurso do criador, enfatizado pelas metáforas beligerantes que constantemente denunciam o inimigo - cuja representação ficcional elementar aponta majoritariamente o regime ditatorial cubano -, gerando, assim, uma obra transgressora. O que entendemos como "munição" na escrita areniana surge pelo inesgotável armamento literário que o escritor reserva nos cartuchos de seu verbo, nas folhas envenenadas de suas narrações, posto que seus maiores golpes expressivos sempre ocultam a detonação enunciativa mediante o aparecimento do inesperado, de um discurso enfatizado pela dor. Frente à necessidade de expor seu posicionamento, em suas narrações-munições, o autor age na escrita como um performer, ${ }^{2}$ que, através desses gestos ${ }^{3}$ literários, intervém no campo da produção literária com ações simbólicas de resistência e de denúncia, sempre pronto para disparar de maneira direta contra o inimigo. Seu alvo principal é o governo castrista e as suas manobras punitivas das liberdades individuais em Cuba no período revolucionário. No caso de Arenas, especialmente

1 "O que chamo intensidade em um conto consiste na eliminação de todas as ideias ou situações intermediárias, de todos os preenchimentos ou fases de transição que o romance permite e inclusive exige" (CORTÁZAR, 1993, p. 390, tradução nossa).

2 "Em quem escreve como performer, o corpo se impõe, nos jogos com a subjetividade e a biografia, a exposição das marcas da vida pessoal (o sexo, a tortura, os territórios ocupados, os medos, as traições) e, sobretudo, pela interseção com a morte, no espaço repetido de recuperar a si mesmo em suas partes, inscrito em algum esquema coletivo e de tempos recuperados" (RAVETTI, 2002, p. 61-62). Para nós, nas narrativas-munições, Arenas exerce o movimento de impor seu corpo, sua subjetividade, as marcas de sua vida pessoal para que ela, em algum momento, seja lida pelo futuro leitor.

${ }^{3}$ Para Agamben (2007), o sujeito que escreve localiza-se dentro e fora do espaço literário, inserido num lugar onde, entre língua e sujeito, está o seu gesto, uma ação. Através desse gesto, "a função-autor aparece como processo de subjetivação mediante o qual um indivíduo é identificado e constituído como autor de certo corpus de texto" (AGAMBEN, 2007, p. 57) cuja vida jogada na obra é passível de investigação. 
nas décadas de 1960 e 1970, período no qual foi obrigado a viver num alcunhado exílio interior. ${ }^{4}$

O reiterado componente político e a violência implícita que projetam as letras dos relatos mais emblemáticos de Arenas palpitam imersos na dupla leitura, espacial e existencial, que demarca uma configuração de escrita primitiva. Toda sua obra está inundada da Cuba de seus pesadelos e sonhos não cumpridos, envilecida por um sentimento de ódio, de rancor alucinado, denunciando que "a sociedade castrista e a sua cultura política se centram em dois temas primordiais: a opressão e hipocrisia gerada por uma prevalente cultura machista e a cruel e implacável persecução da intelectualidade dissidente" (SCHMIDTCRUZ, 2000, p. 28, tradução nossa).

A perseguição constante do governo cubano teve como réplica a palavra envenenada nas últimas obras do escritor. Arenas, no exílio, ressurge de sua morte literária, provocada pela censura, como criador livre, mas de forma ressentida, projetando em suas narrativas uma acusação enérgica contra o sistema castrista ao mesmo tempo que denuncia o seu entorno pessoal e/ou familiar.

\section{0 espaço testemunhal em Arenas}

O grupo de escritores exilados, de gerações próximas à de Reinaldo Arenas, que abandonou Cuba em 25 de setembro de 1980 pelo porto de Mariel - uma comunidade de excluídos que pretende projetar uma luz significativa em suas letras, fulgir além das fronteiras cubanas sua persecução e censura - era composto por extraordinários autores, como: Carlos Victoria (1950-2007), Roberto Valero (1955-1994), Reinaldo García Ramos (1944) e Juan Abreu (1952), entre muitos outros.

Metamorfoseia-se a identidade literária do escritor que combate para tornar visível a memória individual apagada no passado e agora inserida num marco social supostamente democrático, embora, "[p]ara Arenas, o capitalismo, sobretudo o norte-americano, resulte tão nocivo como o dogmatismo dos regimes totalitários" (GUTIÉRREZ, 2002, p. 52, tradução nossa).

\footnotetext{
4 "O exílio interior se manifesta quando o ser humano não pode exercer livremente suas funções cidadãs por estar sumido na marginalidade, ostracismo, prisão, dissidência” (NEGRÍN, 2000, p. 16-17, tradução nossa).
} 
Nesse entorno contaminante para o pensamento e o desenvolvimento emancipatório do poeta cubano, o autor resolve que a melhor maneira de apresentar-se narrativamente será procurar uma forma incisiva que reflita intimamente a marginalização do sujeito dominado e desarticulado impositivamente. No processo catártico surge, então, o autor-testemunha que, para Yúdice (2002, p. 222, tradução nossa), “[...] tentava assentar a responsabilidade da enunciação na voz/escrita de classes e grupos subalternos para assim mudar a sua posição em relação às instituições através das quais se distribuem o valor e o poder".

Nessa posição de subalternidade expressiva padecida em Cuba, a libertação no discurso de Arenas nos Estados Unidos da América vai demarcar a representação em suas letras do espaço social e político que o cercou no passado e que nos pode ajudar a dar verossimilhança aos fatos narrados, suas marcas expiatórias particulares, observando as tragédias coletivas. $\mathrm{O}$ autor precisa contar e testemunhar que foi ele quem enfrentou o sistema ditatorial e que, apesar de tudo, sobreviveu, mas que muitos outros não tiveram a mesma sorte na ilha. Por este motivo, a literatura produzida por Arenas, como um arsenal de acusações, representa todos os afetados pela violência do Estado que nunca puderam denunciar e explanar abertamente sua versão da história.

Existe uma diferença evidente entre o testemunho europeu e latino-americano $0^{5}$ pois, este último, principalmente, traz debates para a representatividade dos sujeitos sem voz. Desta forma, no território latinoamericano, o espaço testemunhal "tem contribuído para o conhecimento e adaptação da psique coletiva à ideia do cubano e do latino-americano, à ideia do autêntico, do verdadeiro, do essencial" (BARNET, 1987, p. 14, tradução nossa).

\footnotetext{
${ }^{5}$ A pesquisadora Valeria de Marco (2004), considerando a crítica voltada para a literatura de testemunho da América Latina, explica-nos que há duas acepções do termo testemunho "que têm em comum a afirmação do vínculo entre a produção literária e o resgate da História contemporânea" (MARCO, 2004, p. 45). Segundo ela, estas duas acepções sustentam-se sobre pressupostos distintos, a saber: "Uma acepção orienta o exame de textos que, construídos a partir de múltiplas combinações de discursos literários, documentais ou jornalísticos, registram e interpretam a violência das ditaduras da América Latina durante o século XX; é ela, em parte, tributária da pauta sobre testemunho formulada pelos intelectuais reunidos no Júri do Prêmio Casa das Américas de 1969. Outra, quase absolutamente hegemônica, emerge na década de 1980, a partir do testemunho de Rigoberta Menchú, e volta-se exclusivamente para a literatura hispano-americana" (MARCO, 2004, p. 46).
} 
Portanto, o depoimento sobre o trauma será exemplar em sua representação da marginalidade em Arenas, embora esteja constituído por uma verdade alterada, isto é, por meio de testemunhos ficcionais exemplares que se constituem como ferramentas imprescindíveis para revelar a vítima-Arenas.

Observamos no processo destrutivo-narrativo do escritor a grande desesperança que alberga boa parte de seus contos. O processo de desmembramento paulatino de Arenas faz-se constatável na transformação radical do autor, da euforia e da ilusão à perda absoluta dos desejos, nesta ordem, nos contos "Comienza el desfile" (1965), "Los heridos" (1967) e "Termina el desfile" (1980), que ilustram o início da revolução, as marcas e lesões que esse período deixou em Arenas e o fim dos ideais, da utopia revolucionária da Cuba no autor. Suas narrativas, de tal modo, constroem-se mediante jogos reminiscentes, fazendo ressurgir, de forma repetida e em uma experiência textual polarizada pela dor e pela amargura numa autorreflexão insistente, uma figura deslocada em Cuba, pois "[...] todo testemunho sobre essa experiência põe em jogo não somente a memória, mas também uma reflexão sobre si mesmo [...] devem ser considerados como verdadeiros instrumentos de reconstrução da identidade, e não somente como relatos fatuais" (POLLAK, 2006, p. 55, tradução nossa).

Através de diversos personagens e histórias autobiográficas, Arenas tenta integrar de forma explícita o sentimento de dever com as vítimas, os fantasmas de seu passado, integrando-as em seus textos e construindo uma narrativa eclética e não onisciente com contínuos vaivéns narrativos.

Essa procura pela identificação mimética presente nos relatos de Arenas convive de forma natural com uma voz multiplicada na escrita. Nesse sentido, a fala textual do "eu coletivo" é complexa, significativa e fragmentária; ela dá contorno a um sinal iterado do exercício testemunhal areniano. Apresenta, portanto, "[...] a pluralidade das narrativas - enquanto possibilidade de afirmação de outras vozes-, que abrem novos espaços para o social, à busca de valores compartilhados e de novos sentidos de comunidade e de democracia" (POLLAK, 2006, p. 29, tradução nossa). No entanto, como Seligmamn-Silva (2003) descreve, a memória "individual", desta maneira, sempre vai formar parte da memória coletiva, articulando-se, em Arenas, com a historiografia de Cuba e conformando, desse modo, três registros possíveis do passado que o escritor precisa 
reconstruir para corroborar os fatos vivenciados em um contexto palpável. Porém, no pensamento de Beverley (2002, p. 25, tradução nossa), “o testemunho não é história no sentido de uma simples aglomeração de particulares; aspira a ser exemplar em sua especificidade", sendo esta concepção de subalterno o que dá lugar à apresentação do narrador dissidente. As interconexões desses três registros do passado individual, coletivo e historiográfico, então, vão erigir um arquivo memorial absoluto tanto para Arenas quanto para seu leitor.

As diferentes narrativas e vozes em perspectiva, assim, pervertem o discurso literário, no qual a fidelidade com os episódios relatados será impossível de recuperar, de forma objetiva, pelo narrador. $\mathrm{O}$ discurso literário de Arenas é, deste modo, implodido diante do desejo do autor de mostrar tudo o que viveu e testemunhou. Diante da impossibilidade de dizer tudo, o narrador perverterá a literatura ao apresentar imagens de memória em colapso que resultam da atividade de lembrar e escrever experiências assinaladas pelo trauma, através de uma linguagem que é insuficiente diante das potencialidades mnemônicas e imaginativas. Desta maneira, "[...] o essencial não pode ser apresentado de modo direto [...] Não há presença originária a ser representada, mas falta, ausência, perda" (SELIGMANN-SILVA, 2003, p. 20-21). Sendo assim, o escritor e personagem-Arenas é vítima de sua simbólica narratividade, pois, ao projetar como alvo o sistema que o oprimiu, não consegue se desvencilhar de um lugar combativo em que também se constitui alvo.

A consciência subalterna de presença e não presença autoral tornase a faceta mais obscura do testemunho areniano, a mais intricada na sua definição, já que poderia interferir no reconhecimento e na valorização do depoimento íntimo-aflitivo do autor. No caso de Reinaldo Arenas, quando esta consciência se introduz nas narrativas que descrevem suas tragédias pessoais, tornam-se visíveis múltiplas interferências pessoais. Por exemplo, a carga implícita da violência filial e do cruel matriarcado o apresenta como vítima e testemunha de um espaço opressivo explicitado nos contos "Los heridos" e em "El hijo y la madre" escrito no mesmo ano, 1967, com a ideia, sempre presente, da morte da mãe. No último relato referido, Arenas (1981, p. 111, tradução nossa) diz: "Fazia tanto tempo que a mãe o regia, sem acompanhá-lo, diminuindo-o, acossando-o, eliminando-o [...] Fazia muito tempo que a mãe estava morta". Nesses relatos, a presença materna como figura castradora e o impulso biográficoficcional hiperbólico no autor, faz com que ele esteja conectado e 
desligado do drama e, ao mesmo tempo, visibilizado e riscado em múltiplas feições íntimas que o identificam e o recusam. A mulher nesse conto, suas ações "refletem a cultura repressiva machista, ainda quando paradoxalmente ela é também submetida pelo sistema de valores que alimenta. São mulheres rejeitadas e reprimidas pela cultura dominante, assim como o é o poeta" (RODRÍGUEZ, 1994, p. 152, tradução nossa).

Essa manifestação da fratura do testemunho e da duplicidade dos rostos que se observam, evidencia-se também nos dois possíveis rostos ou máscaras de Arenas, a ficcional e a real, no conto "Los heridos", que reconhecem sua parte viva e morta, divididos, desse modo, existencialmente e na mesma história. Nesse relato, o autorpersonagem com o mesmo nome que o escritor, "Reinaldo", tenta curar infrutuosamente a um homem moribundo, personagem que se apresenta como um efeito distorcido daquele que tem a tarefa de curá-lo. Desse modo, ambos os personagens se observam e referenciam, pelas marcas biográficas de um Arenas contuso e dividido. Os dois Reinaldos, o vivo e o defunto, ferido de morte como Arenas, no passado, são o mesmo. "O ferido estava morto [...] - Oh Reinaldo, já não tem escapatória - diz então Reinaldo. E nunca se soube a qual dos dois se referia" (ARENAS, 1981, p. 95-96, tradução nossa).

Há, ademais, uma coexistência entre o que o narrador precisa esquecer e relatar, negar e expressar, segundo Arfuch (2007, p. 22, tradução nossa), "sem renunciar a uma temporalização, à procura de heranças e genealogias, a postular diversas relações em presença e em ausência". O autor faz parte de uma história e memória alternativa cubana, expõe-se e, ao mesmo tempo, magnifica uma Cuba anômala e sonhada, desvirtuada mediante imagens, às vezes grotescas, a fim de tentar aproximar o rosto oculto da ilha ao leitor para, dessa forma, descobrir as estratégias sociopolíticas do governo cubano.

A oposição de Reinaldo ao poder hegemônico apresenta outra crônica possível da história quebrando as pautas estabelecidas na forma e no conteúdo, dando ênfase a um componente documental de arestas afiladas. Operando como baluarte da imaginação, sem um controle preciso na escrita, sem fazer parte de um gênero exato e aberto à repulsa e ao prodígio da fantasia, sua narrativa se encaixa na multiplicidade textual contemporânea. Todas as escolhas utilizadas pela testemunhaArenas partem na busca do reconhecimento de sua variante da história, da autodeterminação de seu embate literário constante. 
Sobre a construção testemunhal latino-americana, Hugo Achúgar nos (1992, p. 50, tradução nossa) diz que ela "narra em paralelo não para identificar, mas para confrontar, distingue e não assimila. $\mathrm{O}$ seu desejo é desmontar uma história hegemônica, ao mesmo tempo em que deseja construir outra história que chegue a ser hegemônica". Neste sentido, os relatos testemunhais de Arenas não pertencem a um contexto latino-americano tipificado, pois atuam do mesmo modo que um sujeito alegórico, em um oásis narrativo e sob um tom estilístico exclusivo, sendo herdeiro único de sua própria alteridade. A obra de Arenas se circunscreve, por um lado, literariamente fora do "boom latino-americano" e, por outro, alheia ao conceito determinado de "real-maravilhoso", 6 embora este possa ser parcialmente identificável em muitas passagens de sua obra como, por exemplo, no relato "La vieja Rosa" (1966).

A representação do sujeito crítico se transluz em Arenas, em suas narrativas curtas extremamente politizadas, ideia originária da testemunha, já que, segundo Rojas (2002, p. 27-28, tradução nossa), "O testemunho é evidentemente uma maneira de 'servir ao povo'; nosso serviço aqui é a discussão que entabulam estes trabalhos sobre uma das formas culturais de maior ressonância ética e política hoje".

Neste sentido, é sabido que muitas premissas testemunhais da narrativa cubana se articularam ao redor da revolução, exaltando suas grandes contribuições para o mundo e para a cultura de seu país. Porém, esta tendência oscila até $\mathrm{o}$ viés contrarrevolucionário testemunhal em outros pensadores, como no caso do autor que analisamos neste artigo, com foco no espaço testemunhal de Reinaldo Arenas.

\section{Exemplos de narrações-munições}

Termina el desfile foi um livro de relatos curtos publicado pela primeira vez por Ángel Rama no Uruguai, em 1972, sob o título de Con

\footnotetext{
${ }^{6} \mathrm{O}$ conceito do "real maravilloso" foi concebido pelo escritor cubano Alejo Carpentier (1904-1980), em 1943, e tem raiz em uma viagem para o Haiti. Nas palavras de Carpentier (2010, p. 15): “A cada passo encontrava o real maravilhoso. Mas pensava também que essa presença e vigência do real maravilhoso não era privilegio único do Haiti, mas patrimônio de toda a América, onde apesar de tudo ainda não se parou de estabelecer, por exemplo, um inventário de cosmogonias. O real maravilhoso encontrase a cada passo nas vidas dos homens que inscreveram datas na história do Continente e deixaram sobrenomes que ainda se mantêm". A expressão faz referência ao caráter da realidade americana à europeia.
} 
los ojos cerrados, título, também, de um dos contos do livro. A edição completa avaliada neste trabalho integra nove narrativas breves escritas ao longo de três décadas, oito delas produzidas em Cuba e uma última, que Arenas acrescentou nessa edição, escrita em Miami, com o autor já exilado, e que deu nome ao volume: Termina el desfile (1981). Desta forma, podemos contrastar, num mesmo manuscrito, um discurso de Arenas sob o olhar do regime e outro completamente liberado das ataduras oficiais, residindo nos Estados Unidos da América. Os nove relatos do livro são: "Comienza el desfile", "Con los ojos cerrados", "La vieja Rosa", "A la sombra de la mata de almendras", "Los heridos", "El reino de Alipio", "El hijo y la madre", "Bestial entre las flores" e "Termina el Desfile". Apesar da desconexão enunciativa aparente dos contos e o uso e desuso da verdade e da imaginação num mesmo compêndio, o volume contém muitas afinidades. Na opinião de Mujica (1999, tradução nossa), os nove contos:

[...] têm temas comuns e reiterativos como o são o sentimento de estafa (a nível político e a nível humano), a impossibilidade de amar alguém, a asfixia dentro do seio familiar, a família como uma extensão da opressão política, a relação amor-ódio com a mãe, o tom homossexual, o humor em meio às situações mais trágicas. Porém, os contos que abrem e fecham a edição estão muito relacionados, pois ambos partem de experiências vividas pelo próprio autor: ambos dão testemunho em primeira mão de acontecimentos históricos em que Arenas participou diretamente.

Em Arenas, afluem olhares abertos que oscilam entre dois espelhos quebrados que esboçam, da mesma maneira, uma única imagem que o representa. Sendo assim, os elementos constitutivos dos relatos da infância seriam a duplicidade entre a vida e a "não vida". Isso funcionaria como uma válvula de escape, através da escrita, da violência filial sofrida. Essas problemáticas familiares e de realidade-evasão se encontram nos contos: "Con los ojos cerrados", "Los heridos", e "Bestial entre las flores" nos quais "[o]s personagens se valem da imaginação/fantasia para modificar os mundos opressivos no quais tiveram que viver. Arenas justapõe um mundo interior de inocente fantasia com um mundo vulgar e abusivo" (SOTO, 1990, p. 16-17, tradução nossa).

A defesa da imaginação que o escritor cubano proclama para sobreviver faz parte do desejo do poeta de existir por e para a poesia, para o universo literário, sendo que nas personagens infantis protagonistas 
dos contos há uma duplicidade entre o relatado e o universo da fantasia infantil, "os sonhos do narrador funcionam em dois eixos: como transformação e como desejo. A criança tem que se recriar a si mesmo através de outro para sobrelevar a situação. A imaginação o transforma [...]" (RUÍZ, 2008, p. 79, tradução nossa).

A forte ligação autobiográfica de Arenas estabelece um padrão narrativo reconhecível com variadas ferramentas que acionam a memória e projetam imagens verazes, embora, sublinhadas por uma grande violência ou distorcidas pelo autor pelo forte componente emocional inserido.

\subsection{Comienza el desfile}

A força dramática e legitimidade testemunhal se faz evidente em "Comienza el desfile", pois funciona como uma narração histórica em primeira pessoa que assinala o triunfo da Revolução Cubana em 1 de janeiro de 1959. O narrador converte-se em testemunha direta dos acontecimentos que relata, expondo uma passagem fundamental de sua vida, ao mesmo tempo em que descreve o nascimento da utópica liberação de Cuba, o levante e a vitória dos rebeldes castristas. A população da cidade natal de Arenas - Holguín - é o público que recebe com grande agitação e júbilo a chegada dos guerrilheiros vencedores.

Mostra-se uma das primeiras narrações do escritor com elementos sexuais homoeróticos claramente inseridos, armamento literário ressaltado em vários textos do autor e que, de alguma forma, desafia a evidente rejeição dos homossexuais em Cuba. O furor do triunfo se acrescenta com a excitação visível do protagonista perante a chegada do soldado, objeto de seu desejo. A figura do guerrilheiro idolatrado por Arenas-protagonista, além de projetar o sonho hiperbólico da vitória revolucionária, fundese com um jogo sexual não consumado que o autor constrói através da imagem viril desse ídolo que todo mundo almeja tocar, mas que ninguém pode alcançar. Assim como o sonho idealizado da Revolução Cubana, a corporeidade do jovem revolucionário será inalcançável para o personagem principal. Os símbolos fálicos reconhecíveis no relato são as armas que o rebelde traz. Como Arenas (2011, p. 127, tradução nossa) confessa, "o erótico e o literário marchavam de mãos dadas". Assim, "A escopeta alçada", as "armas cumpridas" ou "a faca" que Arenas emprega no relato como elementos representativos de seu bel-prazer, funcionam como estandartes na luta interior do protagonista, que contém interpretações inerentes muito expressivas. Diz o conto: 
Então tirei a faca que me presenteaste, e que sempre levo embaixo da camisa, e comecei a olhá-lo. E logo depois lhe passei o dedo pelo fio - como gravata - [...] E assim estive muito tempo; passando-lhe a mão [...] Você fala, sempre sorrindo; sempre mostrando a escopeta; mas se alguém tenta tocá-la, você não o permite. (ARENAS, 1981, p. 18-20, tradução nossa)

A carga sensual explícita se respira em todo o relato, como em muitas outras obras do autor, com um componente subversivo e sexual muito intenso.

$\mathrm{Na}$ vida real do autor aconteceu algo semelhante ao explanado no conto "Comienza el desfile". Arenas, com só 14 anos, vai para a Serra com a intenção de se unir ao bando de insurgentes, fugindo da rotina, sob um sentimento de alienação existencial. Nessa narrativa, Arenas tenta se incorporar às guerrilhas de Fidel Castro para lutar contra Fulgencio Batista, ${ }^{7}$ opondo-se aos desejos da família, e com resultados frustrados, já que não foi admitido pelo grupo combatente. Abrolha, novamente, uma voraz intertextualidade com diversas obras de Arenas em relação a este mesmo fato, relatado em Necesidad de libertad (2012, p. 14); no capítulo "Rebelde", da autobiografia Antes que anochezca (2011, p. 66); em El palacio de las blanquísimas mofetas (2001), e numa entrevista realizada por Liliane Hasson (1996, p. 39), de forma quase idêntica. Observamos, por conseguinte, em Arenas, um ciclo de narratividade autobiográfica multiplicada em que o discurso íntimo ultrapassa qualquer limite de reiteração narrativa-vivencial, é uma narração-munição, na qual implode sua subjetividade homoerótica oculta, expressa somente na palavra, assim como a pólvora em estado de inércia nas balas, se expressa com o disparo.

Nesse texto se desmitifica, na opinião de Solotorevsky (1993, p. 41), a ideia projetada geralmente sobre a Revolução Cubana, já que: "A maioria dos rebeldes não tinha uma ideia determinada sobre o futuro nem princípios filosóficos definidos" (ARENAS, 2001, p. 298, tradução nossa). Existe uma indeterminação no conto na admissão ou defesa da realidade revelada. O protagonista não participa na comemoração, não ocorre uma identificação perante a ansiada mudança que oferecia a revolução. Arenas, segundo Maccioni (2013, p. 43), apesar de vencer os rebeldes, sente-se alheio aos acontecimentos históricos detalhados no relato.

7 "Fulgencio Batista foi o principal líder político de Cuba entre os anos de 1933 a 1958 , exercendo o poder presidencial de fato ou de direito, exceto entre 1944 e 1952 " (DOMÍNGUEZ, 1998, p. 113, tradução nossa). 
Para Cusato (1995, p. 78, tradução nossa), “A revolução, a qual o personagem deseja se integrar, efetua-se sem a sua participação ativa. Sua integração se realiza somente depois da vitória revolucionária. Ele se une ao desfile como um número obscuro e anônimo entre os outros". Em "Comienza el desfile", o jovem protagonista não entende as razões de sua luta. Na opinião de Soto (1990, p. 16, tradução nossa), "no final do conto as incertezas do personagem obscurecem os fatos históricos, colocando em dúvida a possibilidade de obter uma visão unificada e estável da história".

No pensamento de Maccioni (2013), Arenas como ser desarticulado que é, repensa o sujeito marginal, adolescente, homossexual e, acima de tudo, poeta, conformando uma identidade condenada por sua singularidade. Este sujeito se desenha fora de qualquer imagem tradicional ou aceitada pelos princípios do movimento popular, que no conto se refletem no aplauso durante a entrada dos guerrilheiros. O personagem-Arenas, pelo contrário, continua sendo um ser à margem, desconexo dessa comemoração, ele é a pólvora oculta nas armas em desfile. Funciona como um estatuto deslocado no meio coletivo, da força de poder que delimita aquele processo revolucionário tão celebrado pela maioria.

\subsection{Termina el Desfile}

Por meio do título Termina el desfile, nome referencial do livro de relatos intitulado de igual forma e escrito em 1980, o escritor elabora uma história antagônica da primeira narrativa desse volume de contos, "Comienza el desfile", relatando uma história terrível e transformadora na vida e pensamento de Reinaldo Arenas. $\mathrm{O}$ autor, com esse relato, fecha, desse modo, um ciclo historiográfico memorial que funciona como uma parábola conclusiva, conforme nos sugere Cusato (1995), e, assim mesmo, completa um ciclo histórico-político e vital do diário narrativo realizado pelo escritor ao abandonar definitivamente Cuba e numa situação mais estratégica para difundir suas narrações-munições.

No começo do conto descobrimos um homem que persegue, enlouquecido, uma lagartixa para se alimentar, num espaço lotado de pessoas famintas e empilhadas umas encima das outras. Em seguida descobrimos que todos aqueles indivíduos são refugiados que se encontram na embaixada do Peru para solicitar asilo político e, assim, fugir de Cuba em 1980, data da escrita do conto e da história relatada. 
Arenas-personagem busca desesperadamente a um amigo para tentar fugir com ele da ilha. Conjeturamos, novamente, que o protagonista se trata do próprio Arenas, biografado dramaticamente e inserido nessa narração de horror. No final do relato, surpreende-nos a visão de seu amigo, que não está no interior da embaixada como o resto dos cubanos refugiados - assim como Arenas-personagem imaginava -, mas fora do local, armado e uniformizado, atuando como membro do regime militar do qual o escritor está tentando fugir. Essa imagem impactante no desfecho da narração constata o emaranhado de traições e desconfianças que os cubanos suportavam na ilha.

Cumpre ressaltar a ferocidade tangível das palavras do escritor nesse conto, sendo a exaltação literária de Arenas sua maior vitória. A luta com o regime ditatorial em Cuba, resistindo pela literatura e para a consecução de suas obras tal qual foram concebidas, foi insistente em seu trajeto criativo, glorificando-se o valor da palavra. Cumpre destacar, assim, o grito essencial do autor no relato:

\begin{abstract}
Meu tesouro, meu tesouro, procuro pelo meu tesouro que agora mesmo eu vou agigantar, minha vingança, meu triunfo que vem engrossando, e já não é uma, nem dez, nem cem, mas centenas. Centenas de folhas roubadas ao sonho, ao terror, ao descanso, ao medo, disputadas a punho limpo ao calor, ao estrondo da rua, dos vizinhos [...] Páginas e mais páginas conquistadas com socos, com tapas, com cabeçadas de fúria, com golpes de fúria (ARENAS, 1981, p. 162-163, tradução nossa).
\end{abstract}

No fim da história, há uma ligação direta com a situação apresentada no início, já que o protagonista, afinal, consegue agarrar a lagartixa. Cria-se um paralelo entre o animal sujo e sem saída com o personagem tentando se evadir do recinto, o qual se alimenta de qualquer coisa e mora, também, entre os escombros da cidade, nos orifícios das paredes, como muitos dos cubanos na ilha. Trata-se de uma imagem metafórica e deformada, que parece comparar o animal com o Arenas perseguido e devorado pelo governo durante sua existência em Cuba.

No conto que fecha o livro, há uma constatação do espírito quebrado do criador. A fala do autor explode no transcurso da história, sem enfeites, apresentando de maneira rotunda o mundo irracional em que viveu até esse momento. Mas, como o escritor, igualmente, reconhece: "O problema não é dizer, "é preciso ir"” (ARENAS, 1981, p. 152, tradução 
nossa). Mostra-se, assim, a impunidade do poder do Estado, na busca de outro território, a dramática crônica do final de um sonho.

\section{Considerações finais}

Em resumo, neste artigo, consideramos que se verificaram os fortes caracteres das narrações-munições testemunhais em Arenas. Estes caracteres assinalam numerosas exacerbações pessoais e literárias e uma violência explícita em seus contos memoriais. A fala da vítima-Arenas surge nos relatos mediante uma verdade transformada e enaltecida. $\mathrm{O}$ autor constrói-se a partir de modelos biográficos intencionalmente desafinados que aturdem por sua repetição e atraem por sua densidade humana.

$\mathrm{Na}$ opinião de Alberto (2004), as narrações de Arenas imitam-se umas às outras, clonam-se, funcionando como um eco ou um grito de terror interminável. Porém, "os ecos nem sempre são entendidos, porque a voz, ao projetar-se, se empasta" (ALBERTO, 2004, p. 242, tradução nossa), sendo essas interferências linguísticas e discursivas ocorrências reiteradas em muitos dos contos do autor. Arenas, em suas narrações breves memoriais, ao mesmo tempo em que extrapola todo seu imaginário histórico e pessoal, precisa lembrar cada ferida. Acontece que, nessa memória da perseguição, vai surgir uma literatura perversa, pois "não se conforma com a morte da história, e [...] pensa que seus combates públicos e privados merecem um lugar em suas páginas" (MANZONI, 2008, p. 163, tradução nossa).

Evidenciamos também, no autor, o elemento patológico presente em suas histórias como resultado do trauma vivido e, em seu discurso testemunhal, como forma de luta e de catarse. Como descreve Mercado (2009, p. 31-32), inspiração e catarse são, equitativamente, as duas categorias que condicionam a transmissão da palavra. Nos contos de Termina el desfile a palavra "estruendo", seu efeito, repete-se como um cântico triunfal, um clamor revolucionário e como o reflexo desse ruído interior que o afogou durante toda a sua existência, o grito de Arenas emerge em todas as narrativas memoriais. Nas palavras de Negrín (2000, p. 37, tradução nossa): "como se o autor sempre tivesse se sentido vigiado por esse estrondo, que é também uma manifestação da fúria e da violência na qual sua vida se desenvolveu [...] Estrondo, enfim, é tudo o que o separa de si mesmo e dos outros". 
Ademais, verificamos que os contos, as narrações-munições das quais se vale o autor, atuaram como argumentos belicosos de ataque e resistência, cuja potencialidade ou expressividade máxima é plausível nas histórias observadas pela força significativa, sendo donas sempre de um discurso proeminente.

Concluindo, com base nas diferentes análises realizadas neste artigo, entendemos que a literatura memorial de Reinaldo Arenas, que caracteriza suas narrativas curtas, se trata de uma poderosa arma literária que revela uma leitura crítica fundamental da história política recente de Cuba a partir de perspectivas autobiográficas diferenciadas.

\section{Referências}

AGAmBEN, G. Profanações. Tradução de Silvino J. Assmann. São Paulo: Boitempo, 2007.

ALBERTO, E. Dos cubalibres: "Nadie quiere más a Cuba que yo". Barcelona: Península, Atalaya, 2004.

ARENAS, R. Antes que anochezca. 8. ed. Barcelona: Tusquets Editores, 2011.

ARENAS, R. El palacio de las blanquísimas mofetas. Barcelona: Tusquets Editores, 2001.

ARENAS, R. Necesidad de libertad. Sevilla: Point de Lunettes, 2012.

ARENAS, R. Termina el desfile. Barcelona: Seix Barral, 1981.

ARFUCH, L. El espacio autobiográfico: dilemas de la subjetividad contemporánea. Buenos Aires: Fondo de Cultura Económica, 2007.

BARNET, M. La novela testimonio: alquimia de la memoria. In:

Cimarrón. Buenos Aires: Ediciones del Sol, 1987, p. 13-14.

BEVERLEY, J. Introducción. In: BEVERLEY, J.; ACHÚGAR, H. La voz del otro: testimonio, subalternidad y verdad narrativa. 2. ed. Guatemala: Abrapalabra, 2002, p. 17-29.

CARPENTIER, A. O reino deste mundo. Portugal: Edições Saídas de Emergência, 2010. p. 11-17.

CORTÁZAR. J. Algunos aspectos del cuento. In: PACHECO, C; LINARES, L. B. (Comp.). Del cuento y sus alrededores: aproximaciones a una teoría del cuento. Caracas: Monte Ávila Editores Latinoamericana, 1993. p. 379-396. 
CUSATO, D. A. Esperanzas y desengaños de una revolución: a propósito de Termina el desfile, de Reinaldo Arenas. Caribana, [S.1.], n. 4, p. 7584, 1995.

DOMÍNGUEZ, J. I. The Batista Regime in Cuba. In: CHEHABI, H. E.; LINZ, J. J. (Ed.). Sultanistic Regimes. London: The Johns Hopkins University Press, 1998. p. 113-131.

GUTIÉRREZ, J. I. G. Reinaldo Arenas: exilios reales y ficcionales. In: MURRIETA, F. (Org.). Creación y exilio: memorias del I Encuentro Internacional con Cuba en la Distancia. Madrid: Editorial Hispano Cubana, 2002. p. 46-53.

HASSON, L. Memorias de un exiliado: París, primavera 1985. In: ETTE, O. (Ed.). La escritura de la memoria: Reinaldo Arenas: Textos, estudios y documentación. Madrid: Vervuert, 1996. p. 35-63.

MACCIONI, L. Retratos del hombre nuevo: figuras de la subjetividad revolucionaria en Pasajes de la guerra revolucionaria y Comienza el desfile. Anclajes, Santa Rosa, v. 17, n. 2, p. 33-45, dic. 2013.

MANZONI, C. P. Nocturno cubano. In: PEÑA, M. T. (Coord.). Del alba al anochecer: la escritura en Reinaldo Arenas. Madrid: Iberoamericana, 2008, p. 145-163.

MARCO, V de. A literatura de testemunho e a violência de estado. Lua Nova, São Paulo, n. 62, p. 45-68, 2004. Disponível em: <http:// www.scielo.br/scielo. php?pid=S010264452004000200004\&script $=$ s ci_abstract\&tlng $=$ pt $>$. Acesso em: 15 abr. 2018.

MATUTE, A. N. En el bosque. Madrid: Real Academia Española, 1998.

MERCADO, T. Testemunho: verdade e literatura. In: GALLE, H. et al. (Org.). Em primeira pessoa: abordagens de uma autobiografia. São Paulo: Annablume, 2009. p. 31-32.

MUJICA, M. C. Aproximación crítica a Termina el Desfile, de Reinaldo Arenas. Espéculo -Revista de Estúdios Literarios, Madrid, n. 12, 1999. Não paginado. Disponível em: <https://webs.ucm.es/info/especulo/ numero12/arenas.html>. Acesso em: 2 jan. 2018.

NEGRÍN, M. L. El círculo del exilio y la enajenación en la obra de Reinaldo Arenas. New York: The Edwin Mellen Press, 2000. 
POLLAK, M. Memoria, olvido, silencio: la producción social de identidades frente a situaciones límite. Buenos Aires: Ediciones Al Margen, 2006.

RAVETTI, G. Narrativas performáticas. In: RAVETTI, G.; ARBEX, M. (Org.). Performance, exílio, fronteiras: errâncias territoriais e textuais. Tradução de Melissa Boechat e Karla Cipreste. Belo Horizonte: Departamento de Letras Românicas, Faculdade de Letras/UFMG, Poslit, 2002. p. 45-68.

RODRÍGUEZ, A. La mujer en la obra de Reinaldo Arenas. In: SÁNCHEZ, R. (Ed.). Reinaldo Arenas: recuerdo y presencia. Miami: Ediciones Universal, 1994. p. 151-159.

ROJAS, R. El campo roturado. Políticas intelectuales de la narrativa cubana de fin de siglo. In: MURRIETA, F. (Org.). Creación y exilio: memorias del I Encuentro Internacional con Cuba en la Distancia. Madrid: Editorial Hispano Cubana, 2002. p. 27-28.

RUIZ, M. E. P. El espejo duplicado al infinito: Celestino antes del Alba. In: PEÑA, M. T. M. de la. Del Alba al anochecer: la escritura en Reinaldo Arenas. Madrid: Iberoamericana, 2008. p. 71-79.

SCHMIDT-CRUZ, C. Disidencia sexual y política bajo el castrismo. E1 testimonio de Reinaldo Arenas en Antes que anochezca. Revista Hispano Cubana, Madrid, n. 8, p. 27-38, oct.-dic. 2000.

SELIGMANN-SILVA, M. História, memoria, literatura: o testemunho na era das catástrofes. Campinas: Editora da Unicamp, 2003.

SOLOTOREVSKY, M. La relación mundo-escritura. Gaithersburg: Ediciones Hispamérica, 1993.

SOTO, F. Conversación con Reinaldo Arenas. Madrid: Betania, 1990.

YÚDICE, G. Testimonio y concientización. In: BEVERLEY, J.; ACHÚGAR, H. La voz del otro: testimonio, subalternidad y verdad narrativa. 2. ed. Guatemala: Abrapalabra, 2002. p. 221-242.

Recebido em: 23 de abril de 2018. Aprovado em: 10 de julho de 2018. 